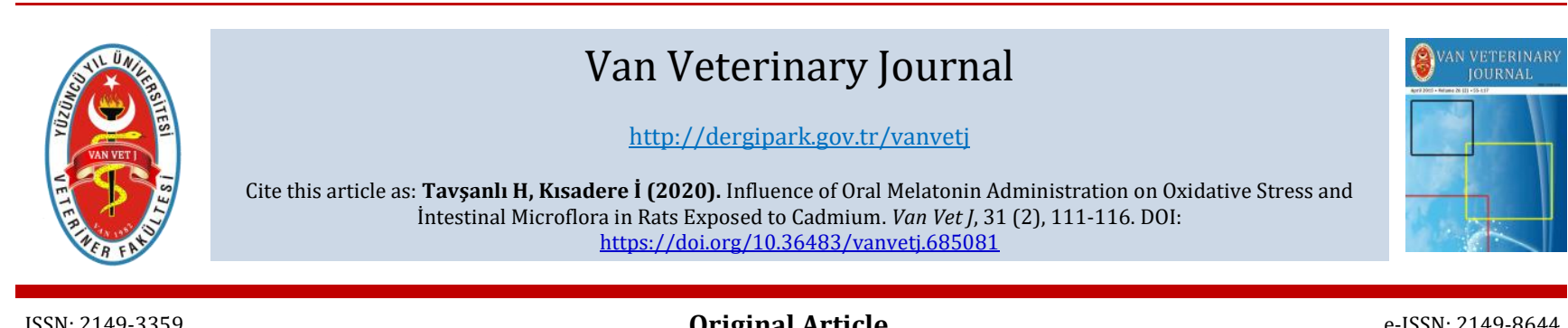

\title{
Influence of Oral Melatonin Administration on Oxidative Stress and İntestinal Microflora in Rats Exposed to Cadmium
}

\author{
Hakan TAVŞANLI'10 İhsan KISADERE2 ${ }^{(0)}$ \\ ${ }^{1}$ Ballkesir University, Faculty of Veterinary Medicine, Department of Public Health, Balıkesir, Turkey \\ ${ }_{2}^{2}$ Balıkesir University, Faculty of Veterinary Medicine, Department of Physiology, Balıkesir, Turkey \\ Received: 05.02.2020 \\ Accepted: 11.05.2020
}

\begin{abstract}
The aim of the present study was to evaluate the effects of oral melatonin treatment on oxidative stress and intestinal microflora in rats exposed to chronic cadmium. Healthy 32 adult male albino Wistar rats were randomly divided into four groups as control ( $C ; n=8)$, cadmium ( $\mathrm{Cd} ; \mathrm{n}=8)$, melatonin (Mlt, $\mathrm{n}=8)$, cadmium + melatonin (Cd + Mlt; n=8). Mlt (100 mg/kg) was orally administered 5 times (Mlt and Cd + Mlt), and $\mathrm{CdCl}_{2}(2$ $\mathrm{mg} /$ day) 3 times a week for 4 weeks to rats ( $\mathrm{Cd}$ and $\mathrm{Cd}+\mathrm{Mlt}$ ). After the treatments, serum total antioxidant status (TAS), total oxidant (TOS) levels as well as plasma ALT, AST, GGT, T.pro, Alb and BUN values were measured. Intestinal contents were aseptically collected, and Enterobacteriaceae, Lactococcus spp. and Lactobacillus spp. counts were performed. As a result, serum TOS levels were defined higher in Cd group than other groups $(P<0.05)$. Lactococcus spp. counts decreased as $0.63 \log$ in $\mathrm{Cd}$ group compared to $\mathrm{C}$ in small intestine, however it increased as $1.15 \mathrm{log}$ in $\mathrm{Cd}+$ Mlt group. In conclusion, $\mathrm{Cd}+\mathrm{Mlt}$ chelate was found benefical for intestinal microflora due to suppressed the Enterobacteriaceae growth, however ameliorated the Cd induced oxidative stress and Lactobacillus spp./Lactococcus spp. rates in the different part of the intestine.

Keywords: Cadmium, Melatonin, Microflora, Oxidative Stress, Rat
\end{abstract}

öz

\section{Kadmiyuma Maruz Kalan Ratlarda Oral Melatonin Uygulamasının Oksidatif Stres ve Bağırsak Mikroflorası Üzerine Etkisi}

Bu çalıșmanın amacı, kronik kadmiyuma maruz kalan ratlarda oral melatonin uygulamasının, oksidatif stres ve bağırsak mikroflorasında bulunan bazı mikroorganizmalar üzerine etkilerini araştırmaktır. Sağlıklı 32 yetişkin erkek albino Wistar rat, kontrol (C; $n=8)$, kadmiyum (Cd; $n=8)$, melatonin (Mlt, $n=8)$, kadmiyum + melatonin (Cd + Mlt; $\mathrm{n}=8)$ olarak rastgele dört gruba ayrılmıștır. Ratlara oral yolla Mlt $(100 \mathrm{mg} / \mathrm{kg}),(\mathrm{Cd}$ ve Cd + Mlt) haftada $5 \mathrm{kez}$ (Mlt ve $\mathrm{Cd}+\mathrm{Mlt}$ ) ve $\mathrm{CdCl}_{2}$ (2 mg/gün) $3 \mathrm{kez}$ olmak üzere 4 hafta boyunca uygulanmıştır. Uygulamadan sonra serum total antioksidan seviyeleri (TAS), total oksidan (TOS) düzeyleri ile plazma ALT, AST, GGT, T.pro, Alb ve BUN değerleri ölçülmüștür. Ayrıca ince ve kalın bağırsak içerikleri ayrı ayrı aseptik olarak alınarak bağırsak florasında Enterobacteriaceae, Lactococcus spp. ve Lactobacillus spp. sayımları yapılmıştır. Bulgu olarak, serum TOS düzeyleri Cd grubunda diğer gruplara göre daha yüksek olarak tanımlanmıştır $(P<0,05)$. Cd grubunda ince bağırsak florasında Lactococcus spp. sayısı C grubuna göre 0,63 log azalırken, Cd + Mlt grubunda 1,15 log artmıştır. Sonuç olarak, Cd + Mlt şelatının Enterobacteriaceae üremesini baskılanması, Lactobacillus spp./Lactococcus spp. oranını düzenlemesi ve Cd'a bağlı gelișen oksidatif stresi azaltması nedeni ile intestinal mikroflora için faydalı olabilir.

Anahtar Kelimeler: Kadmiyum, Melatonin, Mikroflora, Oksidatif Stres, Rat

\section{INTRODUCTION}

Cadmium (Cd) is, a toxic heavy metal, an important environmental pollutant that widely distributed in agricultural and industrial areas, especially in the atmosphere (Cook et al. 1994). It has been used in industrial area as an anti-corrosive agent for steel, iron and other composites. The main source of exposure to the toxic and carcinogenic (as a group I carcinogen) this metal are heating Cd-containing materials such as smelting and electroplating, using of paint pigments and cadmiumnickel batteries, and also living close to extensive industrial areas. Generally, human are mostly exposed to Cd through the intake of contaminated water, food (especially vegetables) or air as well as inhalation of tobacco smoke (Goyer et al. 1986; WHO 1993; ATSDR 1999). 
Although long-term exposure to $\mathrm{Cd}$ causes many toxic effects in various organ and systems such as brain, lung, bones, immune, haemopoietic, endocrine, cardiovascular and reproductive in human and animals, it mainly accumulates in the kidney/liver tissues and impairs their functions. These disturbances lead to elevation of alanine aminotransferase (ALT), aspartate aminotransferase (AST) and blood urea nitrogen (BUN) levels which are indicator markers of the tissue damage in the blood. It is also affected the plasma protein synthesis and rates. Besides, $\mathrm{Cd}$ is known to cause oxidative stress by increasing lipid peroxidation and/or by changing intracellular antioxidant/oxidant rates (Figueiredo-Pereira et al. 1998; Fowler 2009; Satarug et al. 2010).

The gastrointestinal (GI) tract is susceptible to the attacks of foreign harmfull substances which orally ingested. In the normal microflora of GI tract, there is an important relationship between the bacteria population and the intestinal epithelial cells which is known as symbiosis. It play a critical role for health of the organism due to improving the microbial balance, detoxification and elimination of harmful compounds such as heavy metals from the system by removing through precipitation. The presence of commensal bacteria in the intestinal tract also provides the first barrier of defense against pathogenic bacteria. Imbalance in the relationship among the intestinal epithelial cells, pathogen and/or commensal bacteria population causes GI disorders (Tancrede 1992; Bengmark 1997; Hooper et al. 2001; Eckburg et al. 2005). Heavy metals such as mercury (Hg), cadmium (Cd), arsenic (As), chromium (Cr), thallium (Tl), lead $(\mathrm{Pb})$ and pathogens reach GI tract through ingestion of contaminated food and water (Upreti et al. 2004; Inaba et al. 2005; Monachese et al. 2012). However, the toxicological effect of heavy metals, especially $\mathrm{Cd}$, on GI microflora, is still remains unclear.

In recent years, it has been enounced that the harmful effects of Cd can be ameliorated by using some substances which have antioxidant and metal binding properties. Many chelating agents, antioxidants and vitamins have been used to lessen oxidative stress and also tissue damage due to Cd (Pourmorad et al. 2006; Fang 2007; Karabulut-Bulan et al. 2008; El-Boshy et al. 2014). One of them is Mlt (n-acetyl-5-methoxytryptamine) is a hormone secreted from the pineal gland, accepted as a powerful antioxidant and free radical consumer substance due to its lipophilic properties. In addition, it has metal binding properties, and regulatory effect on the intestinal microflora which was also determined, recently (Reiter et al. 2000; Karbownik et al. 2001; Zhu et al. 2018).

Therefore, the present study has been designed to evaluate the effects of oral Mlt treatment on oxidative stress and intestinal microflora in rats exposed to chronic cadmium toxication.

\section{MATERIALS and METHODS}

\section{Animals}

In study, healthy 32 adult male albino Wistar rats (body weight $\sim 200 \pm 30 \mathrm{~g}$ ) were used. During the experiment, rats were housed in standard plastic rat cages (at $23 \pm 2^{\circ} \mathrm{C}$ room temperature, $55 \pm 10 \%$ relative humidity, 12 hours night/day light period) and fed with ad-libitum standard rat feed. The animals also had fresh drinking water during the experiment. All experimental procedures were approved by the Ethical Committee on Animal
Experimentation of the University of Balıkesir (Turkey, project code number 2019/4-6).

\section{Study Design and Experimental Procedure}

After acclimatization, animals were randomly divided into four groups as control (C; $\mathrm{n}=8)$, cadmium $(\mathrm{Cd} ; \mathrm{n}=8)$, melatonin (Mlt, $\mathrm{n}=8)$, cadmium + melatonin $(\mathrm{Cd}+\mathrm{Mlt}$; $\mathrm{n}=8$ ), and following applications were performed;

Control Group $(C)$ : Standard rat feed and fresh drinking water were given to rats ad libitum throughout the experiment.

Cadmium Group (Cd): Cadmium chloride $\left(\mathrm{CdCl}_{2}\right) \quad$ (2 $\mathrm{mg} /$ day) were orally administered to rats 3 times a week for 4 weeks.

Melatonin Group (Mlt): Melatonin (100 mg/kg) was orally administered to rats 5 times a week for 4 weeks.

Cadmium + Melatonin $(C d+M l t)$ : Melatonin $(100 \mathrm{mg} / \mathrm{kg})$ was orally administered 5 times a week, and cadmium chloride $(2 \mathrm{mg} /$ day) was administered 3 times a week for 4 weeks.

At the end of the experiment ( 4 weeks later), the rats were anesthetized by intraperitoneal injection of ketamine/xylazine $(0.1 \mathrm{ml} / 100 \mathrm{mg} /$ body weight $)$ and sacrificed by cervical dislocation technique. Cardiac blood samples were taken via cardiac puncture under the general anesthesia, and collected into heparinized and normal tubes. Plasma and serum samples were separated from the blood samples using a centrifuge (3000 rpm, 25 min, Heichrich, Germany). Obtained plasma and serum samples were stored at minus $80^{\circ} \mathrm{C}$ in a refrigeratior until analysis time.

Determination of total antioxidant and oxidants levels

Serum total antioxidant status (TAS) and oxidant status (TOS) levels were measured by ELISA (Thermoscientific Elisa Reader, USA) using commercial kits (Rel Assay Diagnostics, Gaziantep, Turkey), according to Erel's method which is automated and colorimetric (Erel 2004, 2005).

\section{Determination of some plasma enzyme levels}

Plasma alanine amino transferase (ALT), aspartate amino transferase (AST), gamma glutamyl transferase (GGT), total protein (T.pro), albumine (Alb) and blood urea nitrogen (BUN) values were measured by using biochemical analyser (Architect C-8000, Abbott, USA) with commercial kits according to prospectus of manufacturer.

\section{Microbiological analysis}

During the necropsy, $1 \mathrm{~g}$ intestinal fluid content were aseptically collected from the small and large intestines of the each rats (separately with 3 replicates). Then, they were homogenized in the stomacher for 2 minutes with sterile $9 \mathrm{ml}$ Maximum Recovery Diluent (MRD), serial dilutions were prepared from $10^{-1}$ to $10^{-6}$. For determine to the Enterobacteriaceae count, $1 \mathrm{ml}$ of the dilution was taken and cultured in VRB (Oxoid CM1082) Agar according to the double-plate technique. The plates were evaluated as Enterobacteriaceae because of the observing purplepink colonies after aerobic incubation at $37^{\circ} \mathrm{C}$ for 24 hours (Osman et al. 2006). On the other hand, $0.1 \mathrm{ml}$ of the dilution was taken and cultured in the M17 (Oxoid CM0785) agar according to spread plate technique for despite to Lactococcus spp. count. Then, plates were evaluated as Lactococcus spp. depends on occuring yellowcream colonies after anaerobic incubation at $30^{\circ} \mathrm{C}$ for 24 hours (Lee et al. 2010). For detection of Lactobacillus spp count, $0.1 \mathrm{ml}$ of dilution was cultured on MRS (CM0361) agar. Plates were also evaluated as Lactobacillus spp. due 
to occuring of yellow-cream colonies after anaerobic incubation at $37^{\circ} \mathrm{C}$ for 72 hours (Bauer et al. 2002).

\section{Statistical Analysis}

Statistical differences among the groups were tested by analysis of variance (ANOVA) which is followed by Duncan's test using SPSS for Windows version 25.0.

\section{RESULTS}

Serum TOS levels were defined higher in Cd group than other experimental groups $(P<0.05)$. Mlt treatment alone positive affected the TAS levels in Mlt group animals when compared to $\mathrm{C}, \mathrm{Cd}+\mathrm{Mlt}$ and $\mathrm{Cd}$ groups $(P<0.05)$, shown in Table 1. Plasma ALT, AST, GGT and BUN enzyme levels were detected higher in Cd group when compared to other experimental groups $(P<0.05)$, shown in Table 2 . Abovementioned enzyme levels decreased due to Mlt administration in Mlt and $\mathrm{Cd}+$ Mlt group animals $(P$ $<0.05)$. Besides, T. pro and Alb levels were found the lowest in Cd group when compared the other groups $(P$ <0.05). Administration of Mlt didn't lead to significant change in the T. pro and Alb values in present study. In the small and large intestines of the control group rats, Enterobacteriaceae, Lactococcus spp. and Lactobacillus spp. counts were detected as 4.34, 4.25 log cfu / g; 6.47, 7.09 $\log \mathrm{cfu} / \mathrm{g}$ and 8.37, $8.63 \mathrm{log} \mathrm{cfu} / \mathrm{g}$, respectively. Although the count of Enterobacteriaceae was defined similar in C Mlt and Cd groups, a significant decrease was found in the $\mathrm{Cd}+$ Mlt group in the small intestine $(P<0.01)$. In terms of the count of Enterobacteriaceae in the large intestine, there was not any significant difference among the C, Mlt and Cd + Mlt, it was found a significant difference in Cd group animals $(P<0.01)$. Although there was not a significant difference between the $\mathrm{C}$ and Mlt groups in terms of Lactococcus spp. count in the small intestine, it was determined a significant difference between the $\mathrm{Cd}$ and $\mathrm{Cd}$ + Mlt group animals when compared the control group $(P$ $<0.01$ ), shown in Table 3. In addition, a significant decrease in the count of Lactococcus spp. was observed in the Cd group, however an increase in the $\mathrm{Cd}+$ Mlt group in the small intestine of the rats. On the other hand, Lactococcus spp. count was found similar in $\mathrm{C}$ and $\mathrm{Cd}$ groups in the large intestine of the rats, there was a significant difference between the Mlt/Cd + Mlt and C groups $(P<0.01)$. There was a significant difference between the $\mathrm{C}$ and the other experimental groups according to Lactobacillus spp. count in the small intestine of the rats $(P<0.01)$. When the large intestines were evaluated, it was found that there was a significant difference between the $\mathrm{C}$ group and $\mathrm{Cd}+$ Mlt group according to Lactobacillus spp. count $(P<0.01)$.

Table 1. Serum TAS and TOS values of the rats in different experimental groups

\begin{tabular}{|c|c|c|c|c|}
\hline \multicolumn{5}{|l|}{ Groups } \\
\hline Parameters & $\begin{array}{l}C \\
(n=8)\end{array}$ & $\begin{array}{l}\text { Mlt } \\
(n=8)\end{array}$ & $\begin{array}{l}\text { Cd } \\
(n=8)\end{array}$ & $\begin{array}{l}\text { Cd + Mlt } \\
(n=8)\end{array}$ \\
\hline $\begin{array}{l}\text { TOS } \\
\left(\mu \mathrm{mol} \mathrm{H}_{2} \mathrm{O}_{2} \mathrm{Eq} / \mathrm{L}\right)\end{array}$ & $23.852 \pm 6.860^{\mathrm{ab}}$ & $17.172 \pm 1.996^{b}$ & $39.473 \pm 7.380^{a}$ & $37.042 \pm 4.832^{\mathrm{ab}}$ \\
\hline $\begin{array}{l}\text { TAS } \\
\text { (mmolTrolox Eq/L) }\end{array}$ & $1.743 \pm 0.016^{b}$ & $1.791 \pm 0.015^{\mathrm{a}}$ & $1.027 \pm 0.007 \mathrm{~d}$ & $1.698 \pm 0.177 \mathrm{c}$ \\
\hline
\end{tabular}

a,b,c; The differences between average values indicated by different letters in the same row of the same parameters are important $(p<0.05)$.

Table 2. The average plasma ALT, AST, GGT, total protein, albumine and BUN levels in experimental groups $(\mathrm{X} \pm \mathrm{SEM})$

\begin{tabular}{lllll}
\hline \multicolumn{5}{c}{ Groups } \\
\hline Parameters & $\begin{array}{l}\text { C } \\
(\mathbf{n = 8})\end{array}$ & $\begin{array}{l}\text { Mlt } \\
(\mathbf{n = 8})\end{array}$ & $\begin{array}{l}\text { Cd } \\
(\mathbf{n}=8)\end{array}$ & $\begin{array}{l}\text { Cd + Mlt } \\
(\mathbf{n}=8)\end{array}$ \\
\hline T.Protein (g/dL) & $5.58 \pm 0.14^{\mathrm{a}}$ & $5.21 \pm 0.14^{\mathrm{a}}$ & $4.57 \pm 0.16^{\mathrm{b}}$ & $5.13 \pm 0.10^{\mathrm{a}}$ \\
\hline ALT (U/L) & $37.83 \pm 1.95^{\mathrm{c}}$ & $37.66 \pm 1.20^{\mathrm{c}}$ & $81.00 \pm 5.17^{\mathrm{a}}$ & $72.82 \pm 4.74^{\mathrm{b}}$ \\
\hline AST (U/L) & $60.16 \pm 4.03^{\mathrm{c}}$ & $62.16 \pm 5.17^{\mathrm{c}}$ & $147.0 \pm 16.82^{\mathrm{a}}$ & $107.16 \pm 9.88^{\mathrm{b}}$ \\
\hline GGT (U/L) & $1.16 \pm 0.11^{\mathrm{c}}$ & $1.15 \pm 0.12^{\mathrm{c}}$ & $2.50 \pm 0.23^{\mathrm{a}}$ & $1.40 \pm 0.24^{\mathrm{b}}$ \\
\hline Albumine (g/dL) & $3.50 \pm 0.10^{\mathrm{a}}$ & $3.52 \pm 0.14^{\mathrm{a}}$ & $2.85 \pm 0.22^{\mathrm{b}}$ & $3.54 \pm 0.91^{\mathrm{a}}$ \\
\hline BUN (mg/dl) & $18.71 \pm 1.22^{\mathrm{c}}$ & $16.10 \pm 1.34^{\mathrm{d}}$ & $40.72 \pm 2.26^{\mathrm{a}}$ & $30.27 \pm 2.25^{\mathrm{b}}$ \\
\hline
\end{tabular}

a,b,c,d; The differences between average values indicated by different letters in the same row of the same parameters are important $(p<0.05)$. 
Table 3. The average counts of Enterobacteriaceae, Lactococcus spp. and Lactobacillus spp. in different parts of the rat intestine

\begin{tabular}{|c|c|c|c|c|}
\hline Groups & Intestine & Enterobacteriaceae & Lactococcus spp. & Lactobacillus spp \\
\hline \multirow{2}{*}{ Control (n:8) } & Small & $4.34 \pm 0.08^{\mathrm{ab}}$ & $6.47 \pm 0.00^{\mathrm{bc}}$ & $8.37 \pm 0.46^{\mathbf{a b}}$ \\
\hline & Large & $4.25 \pm 0.00^{\mathrm{ab}}$ & $7.09 \pm 0.34 \mathbf{b c}$ & $8.63 \pm 0.27 \mathrm{a}$ \\
\hline \multirow[t]{2}{*}{ Melatonin (n:8) } & Small & $4.36 \pm 0.46^{\mathrm{ab}}$ & $6.20 \pm 0.36 \mathbf{b c}$ & $8.12 \pm 0.13^{\mathrm{abc}}$ \\
\hline & Large & $5.03 \pm 0.56^{\mathrm{ab}}$ & $8.76 \pm 0.36^{\mathrm{a}}$ & $8.69 \pm 0.39 \mathrm{a}$ \\
\hline \multirow{2}{*}{ Cadmium (n:8) } & Small & $4.68 \pm 0.51^{\mathrm{ab}}$ & $5.84 \pm 0.53^{c}$ & $6.99 \pm 0.45^{d}$ \\
\hline & Large & $5.37 \pm 0.49 \mathrm{a}$ & $6.32 \pm 0.27 \mathbf{b c}$ & $7.39 \pm 0.22^{\mathbf{b c d}}$ \\
\hline \multirow{2}{*}{ Cadmium+Melatonin (n:8) } & Small & $3.56 \pm 0.28 \mathrm{~b}$ & $7.62 \pm 0.38^{a b}$ & $7.25 \pm 0.27 \mathrm{~cd}$ \\
\hline & Large & $4.30 \pm 0.35^{\mathrm{ab}}$ & $7.40 \pm 0.24 \mathbf{b}$ & $8.48 \pm 0.06^{\mathrm{ab}}$ \\
\hline
\end{tabular}

a,b,c,d; The differences between average values indicated by different letters in the same column of the same parameters are important $(p<0.05)$

\section{DISCUSSION}

Although there are many studies about the toxicological effect of heavy metals, especially $\mathrm{Cd}$, on different tissues (liver, kidney and brain) in human and animal body, influences of Cd on GI microflora and its relationship with oxidative stress is still unclear depend on the limited investigations (Gerhardsson et al. 2002; Satarug et al. 2003; Kocak and Akcil 2006; Karabulut-Bulan et al. 2008).

In our study, serum TOS levels were defined higher in $\mathrm{Cd}$ group than other experimental groups. Similarly, Cd induced increased blood TOS levels were also detected by Andjelkovic et al. (2019) in a previous study. In addition, exposure the $\mathrm{Cd}$ reduced TAS and GSH levels, however increased $\mathrm{LPO}, \mathrm{H}_{2} \mathrm{O}_{2}$, TOS, OSI values in sublingual gland and kidney tissue samples which were reported by Kumas et al. (2016) and Kostecka-Sochoń et al. (2018). Influence of acute and chronic Cd toxicity on another important antioxidant/oxidant system parameters such as SOD, GSH and Catalase were also defined by other researchers which was similar with our results, previously (Renugadevi et al. 2010; $\mathrm{Bu}$ et al. 2013; Kanter et al. 2013). On the other hand, Mlt (which is a known antioxidant and free radical scavenger) treatment alone positive affected the antioxidant capacity (TAS) in Mlt group animals when compared to $\mathrm{C}, \mathrm{Cd}+\mathrm{Mlt}$ and $\mathrm{Cd}$ groups in present study. It has been reported that treatment of Mlt to chronically $\mathrm{Cd}$ exposed male Sprague-Dawley rats for 3 months also decreased the MDA levels, but increased SOD, CAT and GSH-Px activities in a previous study (Kaplan et al. 2008). Positive effects of Mlt treatment on Cd induced oxidative damage also confirmed by other researchers (Eybl et al. 2006; El-Sokkary et al. 2009; Shagirtha et al. 2011). It can be considered that the treatment of Mlt ameliorated the $\mathrm{Cd}$ induced oxidative stress in present study.

In our study, an important indicators of liver and kidney functions are plasma ALT, AST, GGT and BUN enzyme levels were detected higher in Cd group when compared to other experimental groups which were corresponding with previous studies (Renugadevi et al. 2009; Lakshmi et al. 2012; Kisadere et al. 2019). On the other hand, abovementioned enzyme levels decreased due to Mlt administration in Mlt and $\mathrm{Cd}+$ Mlt group animals in present study. These results were consistent with Alabbassi et al. (2008) and Hussein et al. (2014). Besides, T.pro and Alb levels were found the lowest in Cd group in this study. It was corresponding with Zohouri and Tekeli (1999), Hussein et al. (2009) and Oyinloye et al (2016). Increased liver and kidney enzyme levels, and reduction of T.pro and Alb values confirm the tissue damege due to chronic $\mathrm{Cd}$ accumulation and toxicity in present study. Administration of Mlt didn't lead to significant change on the T.pro and Alb values, however increased the BUN, ALT, AST and GGT levels in Cd + Mel groups when compared the other groups. It can be explained that Mlt may be partially tolerated the $\mathrm{Cd}$ accumulation and toxiciy in the liver.

In the small intestinal microflora of the rats, neither Cd nor Mlt didn't cause any significant changes in the counts of Enterobacteriaceae in present study. On the other hand, Escherichia coli and Klebsiella spp., which are the members of Enterobacteriaceae group, counts were detected sharply decreased due to exposed the different high doses of $\mathrm{Cd}$ for 45 days in the small intestine of the mouse by Fazeli et al. (2011). Interestingly, Enterobacteriaceae count was detected the lowest in $\mathrm{Cd}+$ Mlt group when compared to other experimental groups $(\mathrm{C}, \mathrm{Cd}$ and $\mathrm{Mlt})$ in small intestines in our study. The reductional effect of $\mathrm{Cd}+\mathrm{Mlt}$ on Enterobacteriaceae counts can be explained by either direct antimicrobial effect of chelate or by decreasing the absorption/absorption rate of $\mathrm{Cd}$, and tissue oxidative stress with prolonging the residence time of $\mathrm{Cd}$ in the small intestine. In present study, eleveted serum antioxidant and decreased oxidant levels can be also confirmed this findings (Chweatiuk et al. 2006). Besides, Cd treatment led to increase Enterobacteriaceae count in large intestine in Cd group animals when compared to C group. It has been reported that Escherichia coli and Klebsiella spp. counts decreased in the large intestine of the mice due to $\mathrm{Cd}$ administration in a previous study which was inconsistent with our study (Fazeli et al. 2011). Although it has been suggested that Mlt regulates the all intestinal microbial flora and thus improving intestinal health in previous studies, it was not observed a significant change in Enterobacteriaceae counts in large intestine of the Mlt/Cd + Mlt group animals (Zhu et al. 2018). These differences can be occured due to different dose, time of exposure to $\mathrm{Cd}$ and/or animal species. In addition, the count of Enterobacteriaceae in the $\mathrm{Cd}+$ Mlt group was similar with the $\mathrm{C}$ group in our study. It is indicated that the chelate stabilizes the Cd-induced tissue/serum oxidative stress, and the increase of Enterobacteriaceae count in the Cd group is thought to be due to the lack of Cd absorption from the large intestines, therefore the 
oxidative stress formed is a suitable environment for the growth of harmful bacteries.

A significant decrease was defined in the count of Lactococcus spp. in both the small and large intestines in $\mathrm{Cd}$ group animals in present study. In addition, an important increase was detected in the $\mathrm{Cd}+$ Mlt group in both intestines in our study. It was also reported by Fazeli et al. (2011) that gram-positive basilcus and enterecocus microorganisms were more sensitive to $\mathrm{Cd}$ toxicity than gram-negative E.coli and Klepsiella species. These results can be explained by the fact that total bacterial rates of microflora varied with decreased count of Enterobacteriaceae due to $\mathrm{Cd}+$ Mlt administration or the high pH in the small intestine (Glombitza 2001; Marrero et al. 2004).

Lactobacillus spp. count was found lower in Cd group than C, Mlt and Cd + Mlt groups in small intestine microflora of the rats in our study. It has been reported by Fazeli et al. (2011) that Lactobacillus spp. count decreased due to different high doses of Cd treatment in small intestines of the mice which was corresponding with our results. Although decreased Lactobacillus spp. counts were detected by Fazeli et al (2011) in large intestines depend on the different doses of $\mathrm{Cd}$, it increased due to Mlt and Cd + Mlt treatments in large intestine of the rats except $\mathrm{C}$ group in our study. It was also reported that Mlt treatment increased the Lactobacillus spp. counts in large intestines of colitic mice which was consistent with present study (Zhu et al. 2018). It can be also expressed that Cd + Mlt treatment may be reduced Enterobacteriaceae count and lead to increase Lactobacillus spp./Lactococcus spp. rates, and/or activated the antioxidant system that can be confirmed by an increase in serum TAS levels in our study (Djurasevic et al. 2016).

\section{CONCLUSION}

Although Lactococcus spp. counts decreased $0.63 \log$ in $\mathrm{Cd}$ group compared to $\mathrm{C}$ group in small intestine of the rats, it increased as $1.15 \log$ in Cd + Mlt group. In addition, $\mathrm{Cd}+$ Mlt showed a lower antimicrobial effect on Lactobacillus spp. than $\mathrm{Cd}$ in the small intestine. The effect of the $\mathrm{Cd}+$ Mlt treatment on lactic acid bacteries in the small intestine showed that $\mathrm{Cd}+$ Mlt chelate can be benefical for intestinal microflora due to suppressed the Enterobacteriaceae growth, however ameliorated the $\mathrm{Cd}$ induced oxidative stress and Lactobacillus spp./Lactococcus spp. rates in the different part of the intestine.

\section{CONFLICT of INTEREST}

The authors declare that they have no conflict of interest.

\section{REFERENCES}

Agency for Toxic Substances and Disease Registry (ATSDR) (1999). Toxicology profile for cadmium. Atlanta, GA: Department of Health and Human Services, Public Health Service; p. 258.

Alabbassi MG, Hussain SA, Shatha HA (2008). Therapeutic effects of melatonin in lead-induced toxicity in rats. Iraqi J Pharm Sci, 17, 47-54.

Andjelkovic M, Djordjevic AB, Antonijevic E, Antonijevic B, et al. (2019). Toxic effect of acute cadmium and lead exposure in rat blood, liver, and kidney. Int J Environ Res, 16(2), 274.

Bauer TM, Fernández J, Navasa M, Vila J, et al. (2002). Failure of Lactobacillus spp. to prevent bacterial translocation in a rat model of experimental cirrhosis. J hepatol, 36(4), 501-506.

Bengmark S (1998). Ecological control of the gastrointestinal tract. The role of probiotic flora. Gut 42, 2-7.

Bu T, Mi Y, Zeng W, Zhang C (2013). Protective effect of quercetin on cadmium-induced oxidative toxicity on germ cells in male mice. Anat Rec, 294 (3), 520-26
Chweatiuk E, Wostowski T, Krasowska A, Bonda E (2006). The effect of orally administered melatonin on tissue accumulation and toxicity of cadmium in mice. J Trace Elem Med Biol 19, 259-265.

Cook CM, Sgardelis SP, Pantis JD, Lanaras T (1994). Concentrations of $\mathrm{Pb}, \mathrm{Zn}$, and $\mathrm{Cu}$ in Taraxacum spp. in relation to urban pollution. Bull Environ Contam Toxicol, 53, 204-210.

Zhu D, Ma Y, Ding S, Jiang H, (2018). Effects of melatonin on intestinal microbiota and oxidative stress in colitis mice. BioMed Res Int, Article ID 2607679,6 .

Djurasevic S, Jama A, Jasnic N, et al (2016). The protective effects of probiotic bacteria on cadmium toxicity in rats. J Med Food, 00 (0), 1-8.

Eckburg PB, Bik EM, Bernstein CN, et al. (2005). Diversity of the human intestinal microbial flora. Science, 308,1635-1638.

El-boshy ME, Risha EF, Abdelhamid FM, et al. (2014). Protective effects of selenium against cadmium induced hematological disturbances, immunosuppressive, oxidative stress and hepatorenal damage in rats. $J$ Trace Elem Med Biol, 29, 104-10.

El-Sokkary GH, Nafady AA, Shabash EH (2009). Melatonin ameliorates cadmium-induced oxidative damage and morphological changes in the kidney of rat. The Open Neuroendocrin J, 2, 1-9 1.

Erel 0 (2004). A novel automated direct measurement method for total antioxidant capacity using a new generation, more stable ABTS radical cation. Clin biochem, 37, 277-285.

Erel 0 (2005). A new automated colorimetric method for measuring total oxidant status. Clin biochem, 38, 1103-1111.

Eybl V, Kotyzova D, Koutensky I (2006). Comparative study of natural antioxidants - curcumin, resveratrol and melatonin- in cadmiuminduced oxidative damage in mice. Toxicology, 225, 150-6.

Fang C (2007). Characterization of polyphenol oxidase and antioxidants from pawpaw ( asimina tribola) fruit. University of Kentucky Master's Theses.

Fazeli M, Hassanzadeh P, Alaei S (2011). Cadmium chloride exhibits a profound toxic effect on bacterial microflora of the mice gastrointestinal tract. Hum Exp Toxicol, 30, 152.

Figueiredo-Pereira ME, Yakushin S, Cohen G (1998). Disruption of the Intracellular Sulfhydryl Homeostasis by Cadmium-induced Oxidative Stress Leads to Protein Thiolation and Ubiquitination in Neuronal Cells. J Biol Chem, 273 (21), 12703-12709.

Fowler BA (2009). Monitoring of human populations for early markers of cadmium toxicity: A review. Toxicol Applied Pharma, 238, 294-300.

Gerhardsson LLU, Englyst V, Lundstrom NG, et al. (2002). Cadmium, copper and zinc in tissues of deceased copper smelter workers. J Trace Elem Med Biol, 16(4), 261-66.

Glombitza F (2001). Treatment of acid lignite mine flooding water by means of microbial sulfate reduction. Waste Manag, 21, 197-203.

Goyer RA (1986). Toxic effects of metals. In: Klassen CD, Amdur MO, Doull J, editors. Casarett and Doull'stoxicology. Macmillan Publishing p.5926. New York.

Hooper LV, Wong MH, Thelin A et al. (2001). Molecular analysis of commensal hostmicrobial relationships in the intestine. Science 2 : 881-884.

Hussein SA, Abd-el-maksoud HA, Agag BI, El-nile MB (2009). Effect of cadmium toxicity on some biochemical blood parameters and their modulation with certain natural antioxidants in rabbits. Benha Ras Surd, 338-62.

Hussein SA, Hassanein MRR, Ali AH (2014). Protective effects of alphalipoic acid against lead-induced oxidative stress in erythrocytes of rats. Benha Vet Med J, 27(2), 382-395.

Inaba T, Kobayashi E, Suwazono $Y$ et al. (2005). Estimation of cumulative cadmium intake causing Itai-itai disease. Toxicol Lett, 159, 192-201.

Kanter M, Unsal C, Aktas C, Erboga M (2013). Neuroprotective effect of quercetin against oxidative damage and neuronal apoptosis caused by cadmium in hippocampus. Toxicol Ind Health 32(3), 541-50.

Kaplan M, Atakan IH, Aydoğdu N, et al. (2008). Influence of Nacetylcysteine on renal toxicity of cadmium in rats. Pediatr Nephrol, 23, 233-41.

Karabulut-Bulan 0, Bolkent S, Yanardag R (2008). The role of vitamin C vitamin $\mathrm{E}$, and selenium on cadmium-induced renal toxicity of rats. Drug Chem Toxicol, 31(4), 413-26.

Karbownik M, Gitto E, Lewinski A, Reiter RJ (2001). Induction of lipid peroxidation in hamster organs by the carcinogen cadmium: melioration by melatonin. Cell Biol Toxicol, 17, 33-40.

Kisadere I, Donmez N (2019). The effects of quercetin on antioxidant system and some blood parameters in rats exposed to acute cadmium toxicity. Eurasian J Vet Sci, 35 (2), 66-70.

Kocak M, Akcil E (2006). The effects of chronic cadmium toxicity on the hemostatic system. Pathophysiol Haemost Thromb, 35(6), 411-16. 
Kostecka-Sochoń P, Onopiuk BM, Dąbrowska E (2018). Protective Effect of Increased Zinc Supply against Oxidative Damage of Sublingual Gland in Chronic Exposure to Cadmium: Experimental Study on Rats. Oxidative Medicine and Cellular Longevity Volume 2018; Article ID 3732842, 8 .

Kumas M, Esrefoglu M, Bayindir $\mathbf{N}$ et al (2016). Protective Effects of Curcumin on Cadmium-Induced Renal Injury in Young and Aged Rats. Bezmialem Science 3, 92-8.

Lakshmi GD, Kumar PR, Bharavi K et al. (2012). Protective effect of Tribulus terrestris linn on liver and kidney in cadmium intoxicated rats. Indian J Exp Biol, 50, 141-146.

Lee KC, Liu CF, Lin TH, Pan TM (2010). Safety and risk assessment of the genetically modified Lactococci on rats intestinal bacterial flora. Int $J$ Food Microbiol, 142(1-2), 164-169.

Marrero J, Gonza'lez LJ, Sa'nchez A et al (2004). Effect of high concentration of Co (II) on Enterobacter liquefaciens strain C-1: a bacterium highly resistant to heavy metals with an unknown genome. Proteomics, 4, 1265-1279.

Monachese M, Burton JP, Reid G (2012). Bioremediation and tolerance of humans to heavy metals through microbial processes: a potential role for probiotics? Appl Environ Microbiol, 78, 6397-6404.

Osman N, Adawi D, Molin G et al. (2006). Bifidobacterium infantis strains with and without a combination of oligofructose and inulin (OFI) attenuate inflammation in DSS-induced colitis in rats. Bmc Gastroenterology 6(1), 31.

Oyinloye BE, Ajiboye BO, Ojo OA et al. (2016). Ameliorative potential of Aframomum melegueta extract in cadmium- induced hepatic damage and oxidative stress in male Wistar rats. J Appl Pharm Sci, 6, 94-99.
Pourmorad F, Hosseinimehr SJ, Shahabimajd N (2006). Antioxidant activity, phenol and flavonoid contents of some selected Iranian medicinal plants. Afr J Biotechnol, 5 (11), 1142-45.

Reiter RJ, Tan DX, Osuna C, Gitto E (2000). Actions of melatonin in the reduction of oxidative stress. A review. J Biomed Sci, 7, 444-58.

Renugadevi J, Milton prabu S (2010). Quercetin protects against oxidative stress-related renal dysfunction by cadmium in rats. Exp Toxicol Pathol 62(5), 471, 81.

Satarug S, Baker JR, Urbenjapol S et al. (2003). A global perspective on cadmium pollution and toxicity in non-occupationally exposed population. Toxicol Lett, 137(1-2), 65-83.

Satarug S, Garrett SH, Sens MA, Sens DA (2010). Cadmium, environmental exposure, and health outcomes. Environ Health Perspect, 118, 182-190.

Shagirtha K, Muthumani M, Prabu SM (2011). Melatonin abrogates cadmium induced oxidative stress related neurotoxicity in rats. Eur Rev Med Pharmacol Sci, 15, 1039-1050.

Tancrede C (1992). Role of human microflora in health and disease. Eur J Clin Microbiol Infect Dis, 11, 1012-1015.

Upreti RK, Shrivastava R, Chaturvedi UC (2004). Gut microflora \& toxic metals: chromium as a model. Indian J Med Res, 119, 49-59.

WHO (World Health Organization) (1993). Evaluation of certain food additives and contaminants, Fortyfirst Report of the Joint FAO/WHO Expert Committee on Food Additives. Technical Report 837.

Zohouri A, Tekeli SK (1999). Ratlarda Kadmiyumun Metabolizma Üzerindeki Etkilerinin Araștırılması. Istanbul Üniv Vet Fak Derg 25(2), 261-71. 